\title{
Why A DeCEDENT SHOUld Be TREATED BETTER THAN A SACK OF FLOUR: SHORTCOMINGS IN PENNSYLVANIA POST- MORTEM RIGHTS
}

\author{
Bradley E. Holuta ${ }^{*}$
}

INTRODUCTORY HYPOTHETICAL

Imagine for a moment the following situation. There is a young couple, newly married and eager to start a family. Both spouses had been working, but the wife has resigned from her job to give the baby complete attention. The couple decides that it will endure this pay cut, for the promise of upcoming life and a loving home life for their child is well worth the sacrifice. The couple arrives at the hospital for what should be one of the most memorable and special days of their lives. All is going as planned, and as the moment of delivery approaches, the excitement continues to grow. Surrounded by their families, the couple begins to realize that this will be even better than they expected. Then the unthinkable happens.

Through a tragic accident of nature, and despite world-class medical care, the baby dies just hours after delivery. What should have been the best day of their lives has now become the worst. As the couple begins to grapple with the fact that they will be childless, little do they realize that their losses are just beginning.

The hospital staff requests permission to perform an autopsy on the body. While this request seems simple enough, the couple politely declines, wishing only to bury the baby and begin healing from the tragic situation. The nursing staff continues pestering the couple to consent to an autopsy, citing the benefits that would accrue to science. The couple finally relents, but on the specific condition that the autopsy be limited to only the baby's colon, which is believed to be the origin of the complications. The couple knows that even a limited autopsy will provide research that may benefit other families, and they can offer these benefits

\footnotetext{
* University of Pittsburgh School of Law, J.D. Candidate, May 2012.
} 
U N I V E R S I T Y O F P I T T S B U R G H L A W R E V I E W

PAGE

while preserving the sanctity of the remainder of the body. Yet despite the explicit instructions, the hospital staff performs an autopsy on the entire body. After the parents find out, they are further devastated. Not only have their wishes been ignored, but the body of their first child has been violated too. Without even an apology, the couple is sent home.

Unfortunately for this hypothetical couple, the current state of Pennsylvania law on the subject of abuse of a corpse consists of two absolute extremes: Full recovery may be had for abuse that rises to the outrageous and wanton level, but zero recovery may be had for conduct at the negligence level. Pennsylvania should adopt the most recent version of $\S 868$ of the Restatement (Second) of Torts and open the door to recovery for negligent abuse; this approach would eliminate the weaknesses in the current categorical approach, bring Pennsylvania into conformity with other states, and make post-mortem rights consistent with other areas of tort law.

This note will begin with an overview of the current state of Pennsylvania law (I), which does not allow recovery for negligent abuse of a corpse. This overview will discuss two categories of conduct: outrageous conduct for which recovery may be had (I-A) and a spectrum of negligent conduct for which the door to recovery is closed (I-B). The note will then argue for a change in Pennsylvania law by comparing Pennsylvania to other states that do allow for recovery (II-A), discussing the ramifications of assessing damages (II-B), criticizing the current rationale for denying recovery (II-C), and discussing the unfortunate formation of a "reverse eggshell skull rule" in tort law (II-D).

\section{Pennsylvania Does not Allow Recovery for Negligent AbUSE}

Calling it an admittedly "difficult and disturbing decision to make," Pennsylvania courts have not yet recognized a cause of action for "negligent abuse of a corpse." That is, mere negligent mishandling of a corpse, absent intentional or wanton conduct, does not currently constitute a cause of action under Pennsylvania law. ${ }^{3}$ Pennsylvania courts have used a two-category test on the subject of abuse of a corpse: In the category of intentional or outrageous abuse, recovery may be had, but in the category of mere negligent abuse, recovery is barred.

\footnotetext{
${ }^{1}$ Hackett v. United Airlines, 528 A.2d 971, 973 (Pa. Super. Ct. 1987).

${ }^{2}$ See Papieves v. Lawrence, 263 A.2d 118 (Pa. 1970).

${ }^{3}$ Hackett, 528 A.2d at 975 .
} 


\section{A. Intentional/Outrageous Category}

Lying within the first category of intentional abuse is the case of Papieves $v$. Lawrence, in which a fourteen-year-old boy was struck by a car and killed. ${ }^{4}$ The driver did not seek medical assistance, nor did he notify the boy's parents. ${ }^{5}$ Instead, the driver took the body to his garage, where he stored it for a few days until burying it in a nearby field. ${ }^{6}$ More than two months later, the remains were unearthed and returned to the boy's parents, who sued the driver for mishandling of the body. ${ }^{7}$ The Pennsylvania Supreme Court noted that the issue of the existence of a cause of action for mishandling the dead had never been presented to an appellate court before. ${ }^{8}$ The court explained that, while some jurisdictions treat a corpse as a quasi-property right of the heirs, "the underlying, and we believe real, issue is the right of a decedent's nearest relatives to protection against intentional, outrageous or wanton conduct which is peculiarly calculated to cause them serious mental or emotional distress."

The court cautioned that all citizens' peace of mind cannot be universally guaranteed, and in some instances, a "toughening of the mental hide is a better protection than the law could ever be." "Yet the court determined that the plaintiffs' situation warranted recovery, for '[t]here can be little doubt that mental or emotional disorders brought on by conduct such as that set forth in the complaint at bar may be every bit as real, every bit as debilitating as ailments which have more obviou[s] physical causes." 11 Because damages arising from abuse of a corpse are more difficult to calculate than other tangible, physical injuries, the court held that such difficulty is not a reason to deny recovery entirely. ${ }^{12}$

The Papieves court also discussed other issues, including the "impact rule," which bars recovery for emotional distress arising out of one's negligent conduct unless the victim is physically impacted or suffers some physical injury from the

\footnotetext{
${ }^{4}$ Papieves, 263 A.2d at 119.

${ }^{5} I d$.

${ }^{6} I d$.

${ }^{7}$ Id.

${ }^{8} I d$. at 120.

${ }^{9}$ Id. at 120-21.

${ }^{10} I d$. at 121.

${ }^{11}$ Id.

${ }^{12} I d$.
} 
U N I V E R S I T Y O F P I T T S B U R G H L A W R E V I E W

PAGE

negligent conduct. ${ }^{13}$ The court noted that the "impact rule" was entirely inapplicable and thus not a bar to recovery in this case, for the conduct at hand involved intentional misconduct. ${ }^{14}$ The court also noted that it was irrelevant that there can be no direct recovery for emotional distress in a wrongful death claim, for to bar recovery in this situation "would have us ignore precisely that aspect of the defendants' alleged conduct which renders it tortious - its intentional and wanton character-and the extraordinary mental distress which is attributable to that conduct."15

The Pennsylvania Supreme Court decided Papieves by expressly adopting $\S 868$ of the first Restatement of Torts, which states "[a] person who wantonly mistreats the body of a dead person or who without privilege intentionally removes, withholds or operates upon the dead body is liable to the member of the family of such person who is entitled to the disposition of the body."16 The court held that "recovery may be had for serious mental or emotional distress directly caused by the intentional and wanton acts of mishandling a decedent's body . . .,"17

\section{B. Negligence Category: Establishment of a Negligence Spectrum}

While Papieves involved the "intentional" category of abuse, the majority of this paper will focus on the latter category of abuse - that which lies entirely within the negligence realm and within which no recovery may be had. ${ }^{18}$ It is true that there are no "degrees of negligence" in Pennsylvania. ${ }^{19}$ But under the broad umbrella of negligent conduct, there is a three-part spectrum, such that some types of negligence are more egregious than other types of negligence, even though they are defined identically as negligence. It is the exploration of this spectrum of negligent conduct which illuminates the weaknesses in Pennsylvania law, for no conduct lying at any location along this vast spectrum is actionable because none of it rises to the intentional/outrageous level mandated by Papieves. ${ }^{20}$ The weakness

\footnotetext{
${ }^{13} I d$.

${ }^{14} \mathrm{Id}$.

${ }^{15} I d$. at 122 .

${ }^{16} I d$. at 119-20 (quoting RESTATEMENT OF TORTS $§ 868$ (1939)).

${ }^{17} I d$. at 121.

${ }^{18}$ See Hackett v. United Airlines, 528 A.2d 971, 975 (Pa. Super. Ct. 1987).

${ }^{19}$ Ferrick Excavating \& Grading Co. v. Senger Trucking Co., 484 A.2d 744, 749 (Pa. 1984).

${ }^{20}$ Papieves, 263 A.2d at 122.
} 
in this approach is that the door to recovery is completely closed, regardless of the level of egregiousness underpinning such negligent conduct. While this might properly bar recovery for slight negligence, the current approach fails to consider that there are more egregious types of negligent conduct that are not actionable under this "all or nothing" approach. This prevents a victim from recovering anything, even though his actual damages would always be proportionate with the level of the tortfeasor's negligence.

\section{Negligence Spectrum: Low Level of Culpability}

At the low level of culpability in the negligence spectrum is the case of Hackett $v$. United Airlines, in which the plaintiff contracted with a funeral director to provide an adequate casket to protect the body of the plaintiff's decedent when transported across the country, where there would be a proper burial. ${ }^{21}$ The funeral director assured the plaintiff that a bronze casket would provide adequate protection for the decedent's body during transport, as opposed to an alternative, such as a shipping crate. ${ }^{22}$ Based on this representation, the plaintiff purchased the bronze casket and shipped the body across the country on United Airlines. ${ }^{23}$ Upon arrival, the plaintiff discovered that the casket had been badly damaged during the flight, and there was also damage to the body inside. ${ }^{24}$ The casket's damaged condition was evident during the funeral proceedings, and the plaintiff suffered severe mental anguish that required medical treatment. ${ }^{25}$

In a lawsuit against the funeral director and airline, the appellate court found that the plaintiff had not set forth a cause of action. ${ }^{26}$ The plaintiff relied on a 1977 revision to the Restatement (Second) of Torts $\S 868$, which states, "One who intentionally, recklessly or negligently removes, withholds, mutilates or operates upon the body of a dead person or prevents its proper interment or cremation is subject to liability to a member of the family of the [decedent] who is entitled to the disposition of the body." 27 The Superior Court noted that the Pennsylvania Supreme Court had not yet adopted the 1977 revision to $\S 868$ of the Restatement,

\footnotetext{
${ }^{21}$ Hackett, 528 A.2d at 972.

${ }^{22} I d$.

${ }^{23} I d$.

${ }^{24} I d$.

${ }^{25} I d$.

${ }^{26} I d$. at 975 .

${ }^{27} I d$. at 973 (quoting RESTATEMENT (SECOND) OF TORTS $§ 868$ (1979)).
} 
U N I V E R S I T Y O F P I T T S B U R G H L A W R E V I E W

PAGE

and the prior holding in Papieves had limited recovery to instances where there was intentional, outrageous, or wanton behavior towards a corpse. ${ }^{28}$ The court noted, "There is no indication whatsoever . . that the Court intended to blanketly sanction any extension of the provided cause of action in accordance with future revisions of, or additions to, Section 868 in later Restatements." 29 Thus, the court held that negligently providing an inadequate casket, which subsequently caused harm to the decedent, was not actionable because the defendants' conduct did not rise to the level of intentional or wanton misconduct. ${ }^{30}$

Returning to our hypothetical involving the hospital-autopsy situation, a slight twist on its facts could produce a situation at the low level of culpability on the negligence spectrum. Suppose that the hospital staff had completely forgotten to obtain any permission whatsoever and then performed an autopsy without any knowledge of the parents' wishes. The hospital's failure to obtain any level of permission (as opposed to obtaining permission and then exceeding its scope) would likely be a mere negligent oversight. This omission would be similar to the selection of an inadequate casket in Hackett. ${ }^{31}$ Had the hospital not sought permission at all but rather performed the autopsy mistakenly believing that consent had been obtained, such conduct would likely give rise to no recovery under the Hackett logic, for it would not rise to the level of intentionality required by Papieves. ${ }^{32}$

\section{Negligence Spectrum: Medium Level of Culpability}

At the medium level of culpability on the negligence spectrum is the case of Whitson v. City of Philadelphia, where a court in the Eastern District of Pennsylvania held that there was no cause of action for negligent abuse of a corpse under Pennsylvania law. ${ }^{33}$ In Whitson, the medical examiner of the City of Philadelphia failed to properly preserve the decedent's body, which prevented the decedent's family from having an open casket funeral. ${ }^{34}$ Yet the Whitson court cited Papieves for its holding that Pennsylvania recognizes a cause of action for

${ }^{28}$ Id. at 974 (discussing Papieves v. Lawrence, 263 A.2d 118 (Pa. 1970)).

${ }^{29} I d$.

${ }^{30} I d$. at 975 .

${ }^{31} I d$. at 972.

${ }^{32}$ Id. at 975 .

${ }^{33}$ Whitson v. City of Phila., No. 07-2832, 2008 WL 4739532, at *5 (E.D. Pa. Oct. 27, 2008).

${ }^{34}$ Id. at *1. 
intentional abuse of a corpse but not for mere negligence. ${ }^{35}$ In contrast to the selection of a casket in Hackett, the conduct in Whitson lies at the medium level of negligence because the negligence directly impacted the body. ${ }^{36}$ Under neither the lowest nor the medium level of culpability may recovery be awarded because the conduct does not rise to the intentional level.

\section{Negligence Spectrum: Highest Level of Culpability}

At the highest level of the negligence spectrum, let us imagine another hypothetical. Suppose that a funeral director is hired to provide embalming services and a casket for a family's decedent. The funeral director has a good reputation in the community for his compassionate work, so the family was comfortable with this choice. Yet through inadvertence and inattention, the funeral director mistakenly cremates the body instead of preparing it for an open-casket viewing. The family arrives for the proceedings, only to be handed an urn containing their loved one's ashes. Though apologetic, the hypothetical funeral director would face no civil liability in Pennsylvania, for he did not act intentionally or wantonly towards the body; he just made a negligent mistake — albeit a grave one. ${ }^{37}$ Such a catastrophic error still escapes liability since it did not come with the requisite intentionality. This conduct is at a higher level of culpability than Whitson because not only did it impact the body directly, but it also involved a complicated, timeconsuming procedure that was performed directly on the body.

Let us return to the hypothetical at the beginning of this discussion. The hospital staff's conduct in exceeding the scope of the autopsy cannot fairly be compared to the intentionally egregious act of burying a body to hide it, as in Papieves, so the hypothetical would lie somewhere within the negligence spectrum. ${ }^{38}$ The hypothetical would likely lie in the middle of the negligence spectrum. Exceeding the scope of permission in the autopsy seems more egregious than the innocent mistake of selecting the wrong type of casket in Hackett. Remember that although Hackett lies at the lowest level on the negligence spectrum, the hospital staff in the hypothetical actively sought permission from the

\footnotetext{
${ }^{35}$ Whitson, 2008 WL 4739532, at *3-4 (citing Papieves v. Lawrence, 263 A.2d 118, 121 (Pa. 1970)).

${ }^{36}$ Cf. Kearney v. City of Phila., 616 A.2d 72, 73-74 (Pa. Commw. Ct. 1992) (denying recovery at the lowest level of negligence where medical examiner's office delayed notifying the decedent's relatives, thereby causing emotional distress but no physical harm to the body).

${ }^{37}$ See Hackett, 528 A.2d at 975.

${ }^{38}$ Papieves, 263 A.2d at 119.
} 
U N I V E R S I T Y O F P I T T S B U R G H L A W R E V I E W

PAGE

decedent's parents and then exceeded it, causing injury to the body directly, as opposed to injuring another medium which then injured the body. ${ }^{39}$

The greatest danger under the current holdings is that damages are prohibited for abuse that does not rise to the outrageous or intentional level. ${ }^{40}$ Regardless of the level of culpability in the actor's negligence, there will be zero recovery for the decedent's family as long as the actor does not act intentionally. While it is perhaps true that miniscule amounts of misconduct at the low end of the negligence spectrum should not afford recovery, the problem with the current approach is that it blocks recovery at all places along the spectrum -including the most egregious levels of negligence. It would be more proper to open the door to recovery for negligence and then to award damages based upon the actual misconduct. Thus, Pennsylvania should adopt $\S 868$ of the Restatement (Second) of Torts, which allows for recovery in instances of negligent conduct where one "removes, withholds, mutilates or operates upon the body of a dead person or prevents its proper interment or cremation." 41

\section{Pennsylvania Should Recognize a Cause of Action FOR NEGLIGENT ABUSE OF A CORPSE}

\section{A. Other States Already Allow Recovery for Negligent Abuse of a Corpse}

If Pennsylvania were to allow recovery for negligent abuse of a corpse, it would not be adopting a radical approach. Instead, Pennsylvania would be joining a growing contingent of states that already allow such recovery.

\section{Texas}

Texas has long recognized a cause of action for negligent abuse of a corpse. ${ }^{42}$ In Missouri v. Hawkins, the parents of a deceased infant shipped the body on a train car to the location where burial would take place. ${ }^{43}$ The parents had placed the body in a casket and then placed the casket into a plain wooden box, which they nailed shut and labeled to indicate that a body was inside. ${ }^{44}$ A railroad employee mistakenly stood the

\footnotetext{
${ }^{39}$ Hackett, 528 A.2d at 972.

${ }^{40}$ Id. at 975 .

${ }^{41}$ Restatement (SECOND) OF TORTS § 868 (1979).

${ }^{42}$ Missouri, Kan. \& Tex. Ry. v. Hawkins, 109 S.W. 221, 224 (Tex. Civ. App. 1908).

${ }^{43} I d$. at 222.

${ }^{44} I d$.
} 
box up on one end, and the box fell down and came open. ${ }^{45}$ The body sustained bruising, particularly in the face region, to such an extent that the family could not get the decedent's eyes to remain shut. ${ }^{46}$ The court allowed the family to recover for their emotional "injuries to the feelings" that resulted from the defendant's conduct, but the court did not allow recovery for the delay in burial caused by the damage to the body. ${ }^{47}$ (However, in a later case, the Texas court allowed a decedent's family to recover for their inconvenience in having to delay funeral services for eight hours when a shipping company failed to timely deliver the body for burial. ${ }^{48}$ )

Hawkins $^{49}$ is analogous to Pennsylvania's Hackett ${ }^{50}$ case in that both involve the negligent transport of a decedent. Hawkins is likely closer to the medium level of culpability like Pennsylvania's Whitson ${ }^{51}$ case because the negligence directly involved the casket containing the body, as opposed to negligence in the selection of that casket in Hackett. ${ }^{52}$ The Texas approach would allow for recovery at the Whitson $^{53}$ medium level of culpability and presumably also at the highest level of negligent culpability along the negligence spectrum.

\section{Ohio}

Ohio courts have held that

[t]he policy of the law to protect the dead and preserve the sanctity of the grave comes down to us from ancient times, having its more immediate origin in the ecclesiastical law. This salutary rule recognizes the tender sentiments uniformly found in the hearts of men, the natural desire that there be repose and reverence for the dead, and the sanctity of the sepulcher. ${ }^{54}$

${ }^{45} I d$.

${ }^{46} I d$. at 223.

${ }^{47} I d$. at 224 .

${ }^{48}$ Lancaster v. Mebane, 247 S.W. 926, 927-28 (Tex. Civ. App. 1923).

${ }^{49}$ Hawkins, 109 S.W. at 222.

${ }^{50}$ Hackett v. United Airlines, 528 A.2d 971 (Pa. Super. Ct. 1987).

${ }^{51}$ Whitson v. City of Phila, No. 07-2832, 2008 WL 4739532, at*1 (E.D. Pa. Oct. 27, 2008).

${ }^{52}$ Hackett, 528 A.2d at 972.

${ }^{53}$ Whitson, 2008 WL 4739532, at*1.

${ }^{54}$ Carney v. Knollwood Cemetery Ass'n, 514 N.E.2d 430, 432 (Ohio Ct. App. 1986) (citing Brownlee v. Pratt, 68 N.E.2d 798, 800-01 (Ohio Ct. App. 1946)). 
In Carney v. Knollwood Cemetery Ass'n, the relatives of a decedent whose remains were unearthed by a cemetery backhoe operator brought a claim based on negligent abuse. ${ }^{55}$ The backhoe had struck the side and top of a rough box, which contained a coffin with the body of the family's decedent. ${ }^{56}$ The court noted that other courts have established a quasi-property right to the custody of a body, to ensure that it be treated with decency and respect. ${ }^{57}$ Yet “'[q]uasi property' seems to be, however, simply another convenient 'hook' upon which liability is hung[] - merely a phrase covering up and concealing the real basis for damages, which is mental anguish." ${ }^{, 5}$ The court thus rejected the theory that a surviving custodian has quasi-property rights in the body of the deceased and instead acknowledged that the cause of action for mishandling a dead body sounds in tort, specifically infliction of emotional distress. ${ }^{59}$

In the case of Frys v. Cleveland, the family of a decedent brought a claim for their emotional distress arising out of a cemetery's conduct in burying the decedent in a temporary location until the body could be buried in its permanent spot. ${ }^{60} \mathrm{~A}$ vault near the decedent's intended spot had encroached into the space, requiring unexpected work that was impractical given the inclement weather conditions. ${ }^{61}$ There was some dispute as to whether the family was aware that the initial spot would be temporary, for the case centered around the emotional distress the plaintiff incurred while attending the second burial in the permanent location. ${ }^{62}$ The plaintiff was distressed by the muddy conditions that resulted from the backhoe tracks from the temporary spot to the permanent location and felt tense and upset afterwards. ${ }^{63}$ The plaintiff ultimately lost her claim, though not because Ohio law did not allow for recovery. Rather, she could not demonstrate that her emotional

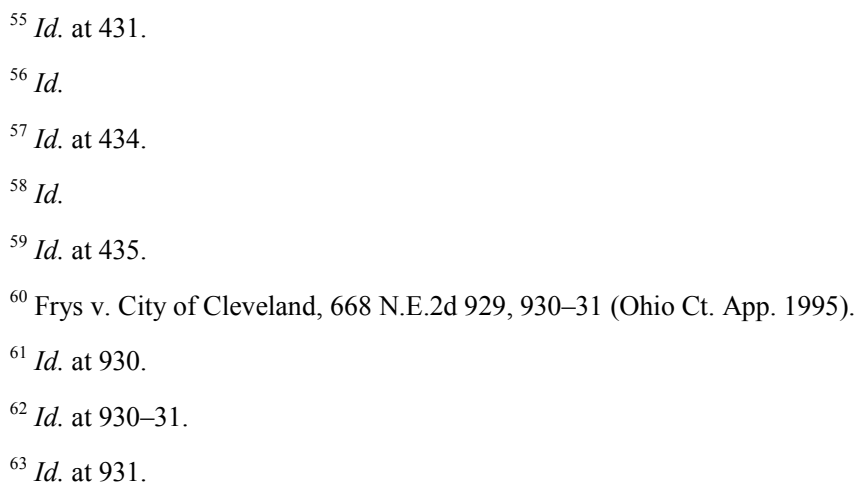


injuries were "serious and reasonably foreseeable." ${ }^{64}$ Ohio law would have allowed recovery for emotional injuries that were serious and reasonably foreseeable. ${ }^{65}$

When applied to the hypothetical that started this paper, Ohio would likely allow the couple to recover for their emotional distress arising from the abuse of their child's body. While the parents may not have a "property right" to the body of their child, these Ohio courts have acknowledged that there are still legitimate interests in this arena that require protection due to their sensitive nature.

\section{Hawaii}

In the case of Guth v. Freeland, a decedent's body was not properly refrigerated by a morgue inside a hospital. ${ }^{66}$ The decedent's family had contracted with a funeral director, who went to retrieve the body from the hospital's morgue, only to find that the body had been kept outside the refrigeration unit. ${ }^{67}$ The body was bloated and already partially decomposed. ${ }^{68}$ The face was purple, the eyes were bulging, the veins were black, and the tongue was swollen and protruding. ${ }^{69}$ The body also smelled terrible and was deemed a "hazzard [sic] to health" by the funeral director. ${ }^{70}$ The funeral director then immediately embalmed the body, which prevented further decay, though without altering the appearance of the body. ${ }^{71}$ The family was told that the desired open-casket funeral could not be held due to the body's condition. ${ }^{72}$ The family did not appear to understand what this meant, so they were shown the body and immediately suffered emotional distress as a result. ${ }^{73}$ Notably, none of the plaintiffs suffered any physical injuries. ${ }^{74}$

\footnotetext{
${ }^{64}$ Id. at 932.

${ }^{65}$ Paugh v. Hanks, 451 N.E.2d 759, 767 (Ohio 1983).

${ }^{66}$ Guth v. Freeland, 28 P.3d 982, 983 (Haw. 2001).

${ }^{67} \mathrm{Id}$.

${ }^{68} \mathrm{Id}$.

${ }^{69} I d$.

${ }^{70} \mathrm{Id}$.

${ }^{71} I d$. at 984 .

${ }^{72}$ Id.

${ }^{73} \mathrm{Id}$.

${ }^{74}$ Id.
} 
PAGE

The plaintiffs' complaint alleged, among other things, negligent infliction of emotional distress. ${ }^{75}$ The court examined Hawaii Revised Statute $\S 663-8.9$, which disallows recovery for negligently inflicted emotional distress arising out of damage to property without a corresponding physical injury. ${ }^{76}$ The court noted that it "would question the policy behind recognizing the value of an attachment to material possessions." ${ }^{, 77}$ Yet the court held that, in this case, the body was not a material possession. ${ }^{78}$ The court cited commentaries explaining that, in the case of corpses, there is "an especial likelihood of genuine and serious mental distress, arising from special circumstances, which serves as a guarantee that the claim is spurious.... Where the guarantee can be found, and the mental distress is undoubtedly real and serious, there may be no good reason to deny recovery." That is, it is unlikely that there will be frivolous emotional distress claims when the damaged object is a corpse ${ }^{80}$ Further, the court noted that in many cases involving the negligent abuse of a corpse, the defendants are in a better position than the decedent's relatives to prevent such abuse and to pay for such damages. ${ }^{81}$

Thus, the Hawaii Supreme Court expressly recognized that it was allowing recovery even though the tortfeasor owed no direct duty to the decedent, who himself is not harmed by the negligent actions. ${ }^{82}$ Yet despite this lack of a direct duty,

\footnotetext{
${ }^{75} \mathrm{Id}$.

${ }^{76}$ The Hawaii Statute provides that:
}

(a) No party shall be liable for the negligent infliction of serious emotional distress or disturbance if the distress or disturbance arises solely out of damage to property or material objects.

(b) This section shall not apply if the serious emotional distress or disturbance results in physical injury to or mental illness of the person who experiences the emotional distress or disturbance.

HaW. Rev. STAT. § 663-8.9 (1995).

${ }^{77}$ Guth, 28 P.3d at 987 (quoting Rodrigues v. State, 472 P.2d 509, 523 (Haw. 1970) (emphasis added)).

${ }^{78} I d$.

${ }^{79} I d$. (quoting W. Page Keeton Et AL., Prosser And KeEton on the LaW OF Torts $\S 54$, at 362 (5th ed. 1984) (emphasis added)).

${ }^{80}$ See id. at 988 .

${ }^{81} I d$.

${ }^{82}$ Id. at 989. 
As a society we want those who are entrusted with the bodies of our dead to exercise the greatest of care. Imposing liability ... will promote that goal. Further, those who come in contact with the bereaved should show the greatest solicitude; it is beyond a simple business relationship - they have assumed a position of special trust toward the family. Few among us who have felt the sting of death cannot appreciate the grief of those bereaved by the loss. It is neither unreasonable nor unfair to expect the same appreciation by those who prepare our dead. ${ }^{83}$

Finally, the court recognized a way of limiting the class of potential plaintiffs, which is necessary since there will oftentimes be unforeseeable plaintiffs to whom the tortfeasor did not owe a direct duty. ${ }^{84}$ Therefore, the court limited recovery to immediate family members "or any other person who in fact occupies an equivalent status." 85

This Hawaii case arguably lies within the highest level of culpability on the negligence spectrum, for the damage to the body and emotional distress to the family were both great. The public policies enunciated in Guth are also applicable to the hypothetical discussed in the "highest level of culpability" section, for the "position of special trust" held by the hypothetical funeral director who mistakenly cremates the body is sufficient to impose liability on im. $^{86}$

\section{B. The Victim's Family Has Suffered Enough from the Abuse, So the Tortfeasor Should Be the One to Pay for the Damages of the Abuse}

We must realize that somebody will suffer a loss in a situation where there is negligent abuse of a corpse, and there are two possibilities as to who pays for these costs. In the first option, the person who abuses a corpse will pay no damages to the decedent's family. The decedent's heirs will suffer emotional distress and damage to their loved one's body while recovering nothing for these damages. The number and duration of the tortfeasor's negligent acts could be limitless, because unless and until his or her conduct rises to the level of intentionality required by the current state of Pennsylvania law, there can be no recovery whatsoever for the

${ }^{83}$ Id. at 989 (quoting Quesada v. Oak Hill Improvement Co., 261 Cal. Rptr. 769, 778 (Cal. Ct. App. 1989)).

${ }^{84}$ Guth, 28 P.3d at 990.

${ }^{85} \mathrm{Id}$.

${ }^{86}$ See id. at $989-90$. 
U N I V E R S I T Y O F P I T T S B U R G H L A W R E V I E W

PAGE

victim's family. ${ }^{87}$ That is, as long as the actor remains merely careless and inadvertent-and not intentional, outrageous, or wanton-he is free to act negligently until the cows come home. ${ }^{88}$

In the second option, upon proving the four traditional elements of a negligence action, the decedent's heirs will be able to recover from the negligent tortfeasor for damages the tortfeasor caused to the decedent's body. In every other area of life, the law requires that a negligent tortfeasor - not the innocent victimpay for the damages he caused, so why should it be any different when the damages were to a dead body? ${ }^{89}$ Given that somebody has to suffer the loss, it seems far more appropriate to require the bad actor to bear that burden than the innocent victim's family. To hold otherwise would create a windfall to the negligent tortfeasor, for he could freely act negligently without paying any damages, which is conduct the law ought to discourage. Now it is true that in some situations of "negligence in the air," a tortfeasor ends up not paying anything despite acting negligently. These are situations where there is negligent conduct but no actual harm suffered. Negligent abuse of a corpse, on the other hand, is not such an "in the air" situation, for there is negligent conduct and harm, so it is not a type of conduct which the law has routinely excused.

\section{There Is No Logical Justification for Barring Recovery for Negligent Abuse}

Pennsylvania courts have not yet articulated a justification for barring recovery for negligent abuse, aside from the fact that Papieves requires the abuse to be intentional, outrageous, or wanton for there to be recovery. ${ }^{90}$ One possible justification could be that damage is not actually done to the plaintiff - the one actually bringing the action in court — but rather to the decedent's body. That is, the plaintiff himself suffered no actual harm, as opposed to a situation in which the plaintiff suffered injuries to his person or damages to his own property. While this is true in actions for negligent abuse of a corpse, this rationale ignores the multiplicity of actions that are routinely brought on another's behalf. The Pennsylvania Constitution explicitly provides that certain actions survive beyond

\footnotetext{
${ }^{87}$ Papieves v. Lawrence, 263 A.2d 118, 120-21 (Pa. 1970).

${ }^{88}$ Hackett v. United Airlines, 528 A.2d 971, 974 (Pa. Super. Ct 1987) (discussing Papieves, 263 A.2d 118).

${ }^{89}$ See G.J.D. v. Johnson, 713 A.2d 1127, 1133-34 (Pa. 1998) (Flaherty, C.J., dissenting) (discussing how a plaintiff's interest in compensatory damages vests at the time the harm occurs).

${ }^{90}$ Papieves, 263 A.2d at 122.
} 
the victim's death. "91 "Survival actions" and "wrongful death" suits are, by definition, brought by a decedent's heirs. ${ }^{92}$ In fact, there is specific statutory authority behind such actions in the Wrongful Death ${ }^{93}$ and Survival Acts. ${ }^{94}$ Moreover, parents bring actions on behalf of their minor children (who own the cause of action) on a regular basis. ${ }^{95}$ Thus, just because the thing that is physically injured by negligent abuse (i.e., the decedent's body) is not the one handling the litigation should not be dispositive, for there are many other situations in which the party in court is not the person who was actually injured.

The basic rationale the Hackett court used for denying recovery was that such recovery had not been allowed before. ${ }^{96}$ Yet America is a nation that was built upon the idea that change should be sought when needed, ${ }^{97}$ and the need for change has continually developed this nation into what it has become. ${ }^{98}$ In the arts, it has often been the case that musical compositions took years to garner acceptance, but

${ }^{91}$ PA. CONST. art. III, § 18.

${ }^{92}$ See Walker v. Roney, 595 A.2d 1318, 1319-20 (Pa. Super. Ct. 1991).

${ }^{93} 42$ PA. CONST. STAT. $§ 8301$ (2006).

${ }^{94} I d . \S 8302$.

${ }^{95}$ See, e.g., Fancsali v. Univ. Health Ctr. of Pittsburgh, 761 A.2d 1159 (Pa. 2000).

${ }^{96}$ Hackett v. United Airlines, 528 A.2d 971, 975 (Pa. Super. Ct. 1987).

${ }^{97}$ This willingness is alluded to in the Declaration of Independence itself:

Prudence, indeed, will dictate that Governments long established should not be changed for light and transient causes; and accordingly all experience hath shown, that mankind are more disposed to suffer, while evils are sufferable, than to right themselves by abolishing the forms to which they are accustomed. But when a long train of abuses and usurpations, pursuing inevitably the same Object evinces a design to reduce them under absolute Despotism, it is their right, it is their duty, to throw off such Government, and to provide new Guards for their future security.

THE DEClARATION OF INDEPENDENCE para. 2 (U.S. 1776).

${ }^{98}$ There was a time, not that long ago, when blacks and whites were lawfully segregated in areas of public accommodation. Courts used to uphold and endorse these differences. At one point, the United States Supreme Court held that

[a] statute which implies merely a legal distinction between the white and colored races-a distinction which is founded in the color of the two races, and which must always exist so long as white men are distinguished from the other race by color- has no tendency to destroy the legal equality of the two races.

Plessy v. Ferguson, 163 U.S. 537, 543 (1896). 
once they did, these pieces remain among the most beloved in the repertoiresuch an extent that one could wonder what we ever did without them. ${ }^{99}$ Where would we as a society be if amputation was the primary cure for an infected toe, or if polio vaccinations were undesirable since they had never been given before? In fact, the Papieves court itself noted that "[e]very cause of action in tort ... was once a novel claim." 100 Thus, Pennsylvania courts should not fear establishing a new cause of action based on these grounds, for all claims were once new.

It is true that the possibility of opening the floodgates to litigation is often cited as a reason for not recognizing a new cause of action, based on the fact that the courts would become inundated. ${ }^{101}$ This is especially a danger when a new cause of action would create negative repercussions on society at large, such as higher insurance costs, for example. ${ }^{102}$ Thankfully, there is not a widespread pandemic of corpse abuse occurring in modern society, so it is unlikely that there will be a stampede of plaintiffs bringing causes of action for the negligent abuse of their deceased relative. Instead, opening the door to recovery for negligent abuse would affect only a small number of persons - the deceased's family, who need that door open the most. This cause of action would also promote public policies behind increasing our appreciation for the dead.

\section{The Current State of the Law Creates a "Reverse Eggshell Skull Rule"}

Adopting $\S 868$ of the Restatement (Second) of Torts would bring Pennsylvania law, with respect to the deceased, into compliance with traditional negligence maxims - that one who owes a duty, breaches that duty, and whose breach was the proximate cause of another's damages, must pay for those damages. ${ }^{103}$ Negligence, by definition, "is not an intentional tort," 104 and

\footnotetext{
${ }^{99}$ When Igor Stravinsky's ballet The Rite of Spring premiered in 1913, its unprecedented style of musical dissonances - deemed "one of the greatest creative leaps in not only the history of music, but in the history of the arts" - was met with such resistance that the concertgoers took to rioting in the streets. Yet today, The Rite of Spring is one of the staples of the standard repertoire. See Renee Montagne, Stravinsky's Riotous "Rite of Spring," NPR (Mar. 21, 2008), http://www.npr.org/ templates/story/story.php?storyId=88490677.

${ }^{100}$ Papieves v. Lawrence, 263 A.2d 118, 120 (Pa. 1970).

${ }^{101}$ Lewis v. Rowland, 701 S.W.2d 122, 124 (Ark. 1985).

${ }^{102} I d$.

${ }^{103}$ Montagazzi v. Crisci, 994 A.2d 626, 631 (Pa. Super. Ct. 2010).

${ }^{104}$ Erie Ins. Exch. v. Muff, 851 A.2d 919, 932-33 (Pa. Super. Ct. 2004).
} 
negligence actions can produce damages for nearly every kind of loss. ${ }^{105}$ Whether the injury is in the form of a physical injury to a person or merely against impersonal property is irrelevant, because the elements of negligence do not distinguish between the two. ${ }^{106}$ As long as a plaintiff can meet the four elements, he or she may recover in a negligence action. ${ }^{107}$

Tort law also recognizes the "eggshell skull" rule, stating that a tortfeasor must take his victim as he finds him and must pay for all damages actually incurred, even if those damages exceed the tortfeasor's original expectations. ${ }^{108}$ For instance, if a tortfeasor strikes a person and injures the victim's index finger, only to discover that the victim is a renowned concert pianist who is now unable to play the piano, the unlucky tortfeasor will be liable for an extraordinary amount of lost wages. Yet under the current state of the law, a tortfeasor who negligently damages a corpse lucks out because his actions harmed a dead body, as opposed to a living being.

Similarly, tort law routinely requires a tortfeasor to repair damaged property. ${ }^{109}$ The victim may recover for damages to restore his property to the preinjured condition. ${ }^{110}$ Suppose that a pedestrian is struck by a vehicle and is carrying a black bag. If there is a sack of flour in the bag and it is destroyed, then the victim will recover only for his destroyed sack of flour. ${ }^{111}$ Likewise, if there is a $\$ 30,000$

${ }^{105}$ See, e.g., Martin v. Evans, 711 A.2d 458, 459-60 (Pa. 1998) (negligence action for property damage to a motor vehicle in an automobile accident); Burnside v. Abbott Labs., 505 A.2d 973, 976 (Pa. Super. Ct. 1985) (negligence action for personal injuries resulting from the ingestion of harmful substances in pharmaceutical drugs); Siegel v. Struble Bros., 28 A.2d 352, 353-54 (Pa. Super. Ct. 1942) (negligence action for damages to a house that resulted from excessive steam arising from the installation of a faulty heating system); Helenthal v. Geller, 13 Pa. D. \& C. 329, 329-30 (C.P. Lancaster 1929) (negligence action involving damage to the plaintiff's flowers and plants).

${ }^{106}$ See cases cited supra note 105.

${ }^{107}$ Montagazzi, 994 A.2d at 631.

${ }^{108}$ Meyer v. Union R.R., 865 A.2d 857, 863 (Pa. Super. Ct. 2004) (recognizing the "eggshell skull" rule).

109 See Siegel, 28 A.2d at 355 (tortfeasor required to pay damages to return a damaged house to its original condition); $c f$. Hackett v. United Airlines, 528 A.2d 971, 975 (Pa. Super. Ct. 1987) (tortfeasor paid nothing for damaging a corpse).

${ }^{110}$ See Harvey v. Susquehanna Coal Co., 50 A. 770, 771 (Pa. 1902) (measure of recovery is the cost of restoring property to its original condition prior to the injury).

111 At Wal-Mart in Western Pennsylvania on September 28, 2011, a five-pound bag of Great Value brand all-purpose, bleached, enriched, and pre-sifted flour cost $\$ 1.94$. 
ceramic sculpture in the bag, the victim may recover for the damaged sculpture. ${ }^{112}$ Yet if there is a body in the bag, there can currently be absolutely no recovery for damage to the body. ${ }^{113}$

In the case of the ceramic sculpture, the tortfeasor would be sickened to learn that he is now liable for $\$ 30,000$ in damages, based on the fact that the tortfeasor must restore the damaged property to its pre-injury condition. ${ }^{114}$ In the case of the groceries, the tortfeasor is delighted to learn that there was only a sack of flour in the bag, such that the damages are only nominal. Yet if the damaged item is a body, the tortfeasor owes nothing, and he is less liable than he would be if he had damaged a sack of flour. ${ }^{115}$ While tortfeasors will occasionally luck out a little bit by becoming liable for only small damages in certain cases, they will luck out entirely if the only thing they damage is the body of a decedent. The miracle of life and the most basic principles of humanity mandate that human beings receive more protection than any other item which the law strives to protect. In particular, the deceased remains of a relative deserve more protection than a sack of flour. Because tort law allows for the full recovery of damages under the eggshell skull rule, it is axiomatic that the courts have taken an opposite position when it comes to damage to a corpse.

\section{CONCLUSION}

Returning to the hypothetical that began this paper, it has been shown that Pennsylvania would side with the tortfeasor and award the family no damages for their loss. As long as the tortfeasor's conduct remains within the negligence realm and does not rise to the level of being outrageous, intentional, or wanton, no recovery will be awarded. As the negligence spectrum has shown, this approach is problematic because it does not allow for recovery in situations involving the most egregious types of negligence. It would make far more sense to allow the victim of minimal negligence to receive nominal recovery, the victim of moderate negligence to recover moderate recovery, and the victim of outrageous misconduct to continue

\footnotetext{
${ }^{112}$ See Harvey, 50 A. at 771 (measure of recovery is the cost of restoring property to its original condition prior to the injury).

${ }^{113}$ Hackett, 528 A.2d at 975 . I will not speculate as to why a person might be carrying a body around in a bag, as that explanation is unnecessary for purposes of this discussion on the state of Pennsylvania law.

${ }^{114}$ Harvey, 50 A. at 771.

${ }^{115}$ See Siegel, 28 A.2d at 355 (tortfeasor required to pay damages to return a damaged house to its original condition); $c f$. Hackett, 528 A.2d at 975 (tortfeasor paid nothing for damaging a corpse).
} 
recovering damages within the intentional realm. Unfortunately, under the current state of Pennsylvania law, only the victim of outrageous conduct will receive anything; the others will not receive a dime.

This approach would be justifiable if there were an articulated and logical reason for it. But Pennsylvania has rested on the precedent that it simply has not done so before. This contradicts the law's approach to all other types of negligent conduct, wherein the tortfeasor pays for the damages he causes. It also forces the innocent victims of negligent abuse to suffer the costs of damages that they had no part in creating and essentially awards windfalls to negligent actors. Further, Pennsylvania has continually resisted the trend adopted by a growing number of other states.

While the hypothetical examples may be criticized as being far-fetched or extreme, the results under the current state of the law remain absolutely true. Until the Pennsylvania courts alter the current approach, the families described throughout this note will inevitably go from being hypothetical discussions to realworld tragedies. 